\title{
Erratum to: Mannose: a potential selection system for genetic transformation of annatto
}

\author{
V.B. PAIVA NETO* ${ }^{1}$, C.R. CARVALHO** and W.C. OTONI \\ Departmento de Biologia Vegetal/BIOARGO* and Departmento de Biologia Geral**, \\ Universidade Federal de Vicosa, 36570-000 Vicosa, MG, Brasil

\section{Erratum to: Biologia Plantarum} \\ DOI:10.1023/B:BIOP.0000023891.16785.fc
}

To the end of legend to Fig. 2 it is necessary to add following information:

The photographs of control materials present in part $C$ and $E$ were already presented in article focused on influence different growth regulators published in journal Plant, Cell Tissue and Organ Culture 75: 159-167, 2003.

The publisher apologize for this error. 